\title{
Release of Base and Potentially Harmful Metals from Waste Deposits at a Former Uranium Mine in Eastern Finland
}

\author{
Hanna Tuovinen ${ }^{1}$, Daniela Vesterbacka ${ }^{1}$, Kai Kaksonen ${ }^{1}$, Juhani Virkanen ${ }^{2}$, David Read ${ }^{3}$, \\ Dina Solatie $^{4}$, Jukka Lehto ${ }^{1, *}$ \\ ${ }^{1}$ Department of Chemistry, Radiochemistry, University of Helsinki, Helsinki, Finland \\ ${ }^{2}$ Department of Geosciences and Geography, University of Helsinki, Helsinki, Finland \\ ${ }^{3}$ Department of Chemistry, University of Surrey \& National Physical Laboratory, Guildford, UK \\ ${ }^{4}$ Finnish Radiation and Nuclear Safety Authority, Rovaniemi, Finland
}

Email address:

jukka.lehto@helsinki.fi(J. Lehto)

${ }^{*}$ Corresponding author

\section{To cite this article:}

Hanna Tuovinen, Daniela Vesterbacka, Kai Kaksonen, Juhani Virkanen, David Read, Dina Solatie, Jukka Lehto. Release of Base and Potentially Harmful Metals from Waste Deposits at a Former Uranium Mine in Eastern Finland. International Journal of Environmental Monitoring and Analysis. Vol. 7, No. 4, 2019, pp. 85-92. doi: 10.11648/j.ijema.20190704.12

Received: August 21, 2019; Accepted: September 10, 2019; Published: September 27, 2019

\begin{abstract}
Leaching of metals ( $\mathrm{Fe}, \mathrm{Mn}, \mathrm{Cu}, \mathrm{Co}, \mathrm{Ni}, \mathrm{Zn}, \mathrm{Cr}, \mathrm{Cd}, \mathrm{Pb}$ ) and arsenic from mine wastes and their accumulation in waters, soils and sediments have been determined at the former Paukkajanvaara uranium mine in Eastern Finland. A smallscale test mine, operating in $1959-1960$, generated $7,300 \mathrm{~m}^{3}$ of waste rock and $12,000 \mathrm{~m}^{3}$ of mill tailings, which were covered with soil and till in the early 1990s. These two materials, waste rock and mill tailings, were studied as possible sources for metal contamination in surrounding water systems. Water samples from a nearby pond and streams flowing from the site into the pond were collected. In addition, soil, pond sediment and mill tailings samples were taken and metals were leached from them with strong acids. Metal concentrations in the water samples and acid leachates were measured with ICP-MS. Nickel and arsenic concentrations in stream water were seen slightly elevated when compared to natural Finnish waters and metal concentrations in lake sediments show an increasing trend with time, both indicating long term leaching of metals from the waste deposits. All other metal concentration measurements revealed no elevated concentrations. In conclusion, we may state that the site is not a big if any threat to the environment and humans.
\end{abstract}

Keywords: Mill Tailings, Waste Rock, Mobilization, Potentially Harmful Metals, Uranium Mine

\section{Introduction}

Mining industries produce large amounts of solid material which needs proper management and disposal in order to avoid contamination of the environment. Leaching of metals from waste deposits into surrounding water is the major pathway of contamination [1]. Due to the increasing general concern about environmental and health effects of mining activities and due to the more stringent authoritative regulations, the studies on pollution effects of mining industries have increased in a number of countries [2-4].

Pilot-scale uranium mining at Paukkajanvaara, Joensuu, eastern Finland started in 1959 in order to assess the feasibility of large scale uranium extraction. The operations were focused on two quarries where the reported uranium content in ores varied between $0.075 \%$ and $0.143 \mathrm{wt} \%$ [5]. On-site mining and ore processing activities included removal of waste rock (mainly gangue minerals), ore crushing, grinding and concentration of uranium by acid dissolution and precipitation with either sodium hydroxide or lime. The average recovery of uranium was approximately $73 \%[5,6]$.

Between 1959 and 196130,000 tonnes of ore were extracted from the mine and about 27 tonnes of uranium concentrate produced. The mining proved to be uneconomic, and operations ceased in 1961. The site was left untouched for almost 30 years until the Finnish Radiation and Nuclear Safety Authority (STUK) initiated a survey of the site, as a 
result of which, the area was remediated. Remediation involved covering the mill tailings and waste rock with respectively, a $30 \mathrm{~cm}$ layer of clay and $1.2 \mathrm{~m}$ of till. In 1994, the mine area was released without restriction for outdoor use. $[5,6]$

Waste generated during processing comprised waste rock $\left(7,300 \mathrm{~m}^{3}\right)$ and fine-grained mill tailings $\left(12,000 \mathrm{~m}^{3}\right)$. The former was piled alongside the open mine pits whereas mill tailings were placed in a shallow depression between the pits and an adjacent natural pond (Iso Hiislampi). Tailings originating from partial dissolution of the ore by sulphuric acid were primarily thought to contain refractory components. Initially therefore, no technical barriers were constructed to prevent release of contaminants from the tailings to the Iso Hiislampi pond [7]. Subsequently, as the tailings deposit filled with water, a damn was constructed between the tailings and Iso Hiislampi to act as a protective barrier.

Paukkajanvaara has been studied extensively in terms of its radiological impact, both prior to remediation $[5,8]$ and more recently [9]. In the latter study, it was shown that ${ }^{226} \mathrm{Ra}$ has been mobilised from the waste rock pile and possibly, also from the mill tailings. Mining and ore processing also have the potential to increase the mobility of potentially harmful metals and arsenic but to date, very little is known of their behaviour at the site. This paper aims to rectify the situation by characterising their mobilisation from the waste rock pile and mill tailings together with their movement through surface waters and accumulation in soil and sediments. Water and solid samples were taken from the waste materials, along a transect from the waste to the Iso Hiislampi pond and of the pond itself via depth-profiled bottom sediment cores.

Many of the metals present at the Paukkajanvaara site (e.g. $\mathrm{Fe}, \mathrm{Co}, \mathrm{Mn}, \mathrm{Zn}, \mathrm{Cu}, \mathrm{Ni}, \mathrm{Cr}$ ) are essential trace nutrients for plants and animals but become toxic at high concentrations; several species of these metals are toxic even at low concentrations. Other contaminants present $(\mathrm{Cd}, \mathrm{As}, \mathrm{Pb})$ have no known biological function. Over time, the behaviour of these pollutants in the mill tailings will be influenced by environmental processes particularly those caused by surface and groundwater leaching, which in turn is affected by ambient conditions, including $\mathrm{pH}$, temperature, redox potential and the presence of organic matter. As a result, dissolved metals may persist in solution, precipitate or co-precipitate with other components in the tailings and be adsorbed onto minerals surfaces or organic matter. A major concern of contaminants in solution is oxidation of sulphide minerals and subsequent development of acid mine drainage (AMD). This could lead to further leaching of metals from waste left on-site. In the case of Paukkajanvaara, the main source is waste rock, which contains significant quantities of sulphides, primarily pyrite $\left(\mathrm{FeS}_{2}\right)$. The degree to which each contaminant is mobilised will depend on the type of ore (mineralogy, physical form) and the milling process [10-12]. In the event that potentially harmful metals are mobilised, they may contaminate local water courses and pollute drinking water. Other potential exposure pathways include fish, wild berries and mushrooms commonly consumed by the local population.

\section{Experimental}

\subsection{Site Description}

Paukkajanvaara (N 6981372, E 653304, ETRSTM35FIN) is located in eastern Finland approximately 40 $\mathrm{km}$ north east of the city of Joensuu. The region belongs to the southern-boreal vegetation zone. The climate is temperate: in Joensuu, July and February mean temperatures are $16^{\circ} \mathrm{C}$ and $-9^{\circ} \mathrm{C}$, respectively. The mean annual precipitation is ca. $600 \mathrm{~mm}$. The Paukkajanvaara uranium deposit is located at an unconformity between Archean basement rocks and Paleoproterozoic metasediments, which are intruded by mafic dikes [13]. The uranium ore bodies are located at the contact between a mafic dyke and its country rocks; the latter are composed of quartzite, meta-conglomerate, sericite-quartz schist and Archean basement gneisses. The deposit consists of two main ore bodies, termed Mårtensson and Kunnansuo. The main uranium ore minerals present are uraninite/pitchblende $\left(\mathrm{UO}_{2} / \mathrm{U}_{3} \mathrm{O}_{8}\right)$ and secondary uranophane $\left(\mathrm{Ca}\left(\mathrm{UO}_{2}\right)_{2}\left(\mathrm{SiO}_{3} \mathrm{OH}\right)_{2} .5 \mathrm{H}_{2} \mathrm{O}\right)$. Brannerite ((U, $\left.\mathrm{Ca}, \mathrm{Y}, \mathrm{Ce})(\mathrm{Ti}, \mathrm{Fe})_{2} \mathrm{O}_{6}\right)$ and coffinite $\left(\mathrm{USiO}_{4}\right)$ are present as accessory phases [14]. Uranium minerals occur mainly as fracture fillings, since uranium deposition post-dates emplacement of the mafic dykes. The major minerals in the waste rocks are quartz and sericite. The ore also contains magnetite, hematite, and galena with minor iron sulphides and chalcopyrite [13].

\subsection{Sampling and Sample Preparation}

Sampling locations are shown in Figure 1. The aim of the study is to evaluate release of potentially harmful metals and arsenic from two potential sources on the site, the waste rock pile (1) and the mill tailings (2). In order to study releases from the waste rock, soil samples (3) and run-off sediment samples (4) were taken from its southeastern edge (5) where a small stream emanates (not shown in Figure 1); the latter is the assumed discharge pathway for aqueous releases from the pile. This stream flows into another stream (6), that is not affected by the waste rock pile at upstream, and thence to Iso Hiislampi (7), a small pond adjacent to the site. Both water and sediment samples were taken from the streams and the pond. The mill tailings can leach into Iso Hiislampi directly and via the stream flowing on its eastern side. Therefore, soil samples were taken between the tailings and the lake (8) and between the tailings and the stream (9). Sampling was undertaken in September 2010 and June 2012. 


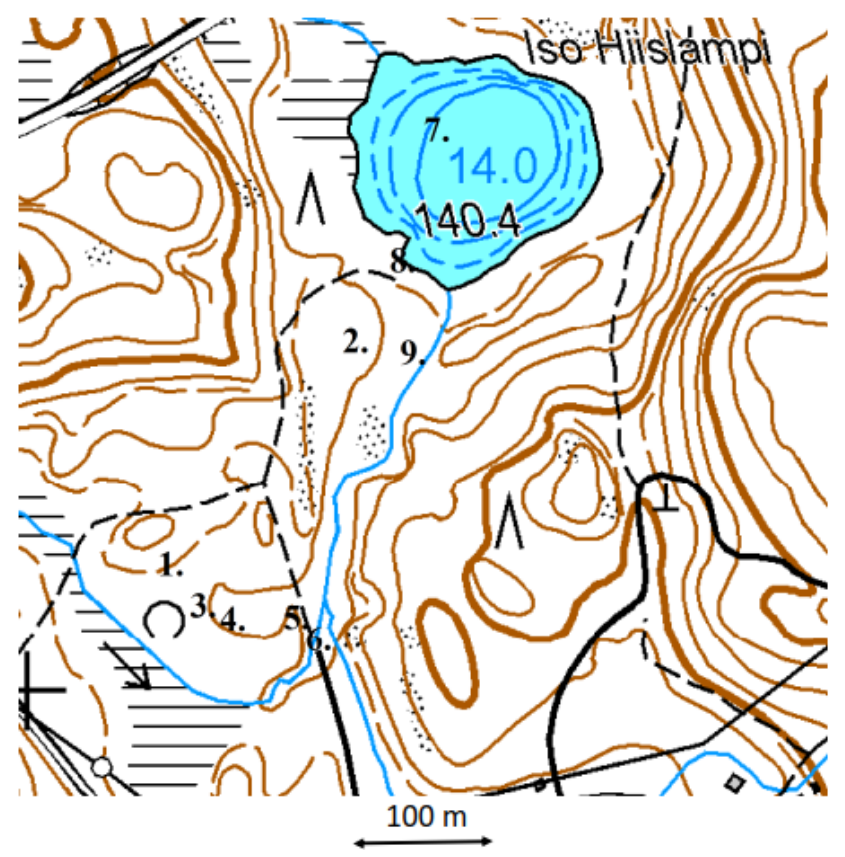

Figure 1. Sampling points at the former Paukkajanvaara mining site.

Three sediment cores were collected from the bottom of the Iso Hiislampi pond using a Limnos sediment sampler. The cores were then sliced into layers of $1 \mathrm{~cm}$ thickness, sealed in plastic boxes and frozen. Soil samples were collected using a topsoil drill and divided into sub-samples on site according to their material content. A total of 15 soil core samples were collected with a $20 \mathrm{~cm}$ topsoil corer at the mining site: five samples near the waste rock pile, six between the mill tailings area and Iso Hiislampi and four between the mill tailings and the stream. The cores were divided into three vertical sub-samples, the uppermost layer representing organic matter and the others mineral soil. Eight run-off sediment samples were also collected near the waste rock pile using a shovel. Three samples of mill tailings at various depths were collected by the Geological Survey of Finland using a GM50 Drill. Water samples $\left(10 \mathrm{~cm}^{3}\right)$ were filtered on site with a $0.45 \mu \mathrm{m}$ polypropene filter to pretreated tubes containing $0.05 \mathrm{~cm}^{3}$ concentrated nitric acid. A total of 19 water samples were collected including two reference samples well away from the contaminant sources.

The pond sediment samples were dried in the laboratory using a vacuum drier (Christ Alpha 1-4 LSC). Other solid samples were dried at $40^{\circ} \mathrm{C}$ and the samples containing organic matter at $60^{\circ} \mathrm{C}$ for one week and sieved through a 2 $\mathrm{mm}$ sieve to remove coarse material. The pond sediments were not sieved since they were already of sufficiently small grain size $(<2 \mathrm{~mm})$. The solid samples were digested in concentrated nitric acid in a microwave oven (MARS 5) for metal analysis by inductively coupled mass spectrometry (ICP-MS). Nitric acid was chosen based on comparative digestion experiments performed previously on the same materials [15]. The acids used were all suprapur grade (Merck), suitable for ICP-MS. After cooling, the digest was filtered through a $0.45 \mu \mathrm{m}$ polypropylene filter and stored in Nalgene containers in the refrigerator pending analysis.

\subsection{Determination of Metal Concentrations by ICP-MS}

Elemental compositions were determined in water samples and from the microwave digestions using an Agilent 7500 ce/cx ICP-MS. The resulting spectra were analysed using Masshunter spectral analysis software. Elemental standard solutions were prepared by diluting multielement standard solution (Merck) with $5 \% \mathrm{HNO}_{3}$. Water used in preparation of dilute nitric acid was purified using a Milli-Q water purification system (Millipore, USA). Two reference waters (Environment Canada, Certified Reference Materials, trace element fortified calibration standard, TM-27.3, lot 0510 and TMDA-64.2, lot 1010, National Water Research Institute, Certified Reference Materials) and two reference sediments (HR-1 Humber River sediment for Trace Elements, Lot number 001, Canadian Certified Reference Materials Project and Lake Sediment Reference LKSD-4 lot number 1563) were included for quality assurance purposes. Overall measured values correlate well with those reported though on average, the measured values were $3 \%$ higher (from- $8.3 \%$ to $+19 \%$ for various references) (Table 1). The largest difference was seen with $\mathrm{Ni}$ in the case of sediments where the measured values were $169 \%$ and $72 \%$ higher than expected. These high differences results in rejecting $\mathrm{Ni}$ results for solid samples.

Table 1. Results of quality assurance testing for metal concentrations in water (TMDA-64.2 and TM-27.2) and sediment (HR-1 and LKSD-4) reference samples. For HR-1 and LKSD-4 partially soluble values were used. Difference: + measured value higher than certified values, - measured value lower than certified value.

\begin{tabular}{|c|c|c|c|c|c|c|c|c|}
\hline \multirow{2}{*}{ Element } & TMDA-64.2 & Differene & TM-27.3 & Difference & HR-1 & Difference & LKSD-4 & Difference \\
\hline & Certified & $(\%)$ & Certified & $(\%)$ & Certified & $(\%)$ & Certified & $(\%)$ \\
\hline $\mathrm{Cr}$ & 290 & -5.9 & 1.74 & 2.3 & 122 & -13 & 21 & 9.5 \\
\hline $\mathrm{Cd}$ & 266 & -25 & 1.05 & -30 & 3.83 & -15 & 1.9 & 32 \\
\hline $\mathrm{Mn}$ & 295 & -7.5 & 2.25 & -20 & 511 & -4.9 & 430 & 19 \\
\hline $\mathrm{Fe}$ & 306 & -9.8 & 10.9 & -20 & 28289 & -5.2 & 27000 & 25 \\
\hline $\mathrm{Ni}$ & 263 & 13 & 2.42 & 17 & 36 & -169 & 32 & -72 \\
\hline $\mathrm{Co}$ & 254 & -7.1 & 2.05 & -4.9 & 10.5 & -14 & 11 & 27 \\
\hline $\mathrm{Cu}$ & 274 & -14 & 6.19 & -10 & 81.2 & -21 & 30 & 3.3 \\
\hline $\mathrm{Pb}$ & 288 & -11 & 2.86 & -11 & 134 & -24 & 93 & 15 \\
\hline As & 162 & -6.2 & 2.13 & -5.6 & 5.95 & -21 & 12 & -8.3 \\
\hline $\mathrm{Zn}$ & 310 & -11 & 16.2 & -6.7 & 1136 & 4.2 & 189 & 49 \\
\hline Mean diff & & -8.4 & & -9.0 & & $-13^{*}$ & & $19^{*}$ \\
\hline
\end{tabular}

excluding values for $\mathrm{Ni}$ 


\subsection{Identification of Solid Phases in Pond Sediments by $X R D$}

The Iso Hiislampi pond sediments were analysed by X-ray diffraction (XRD) using a Philips X'Pert MPD diffractometer and spectra recorded in the range $2-70^{\circ} 2 \theta$ (step size $0.02^{\circ} \theta$, time per step $1.00 \mathrm{~s})$. The principal phases present were identified with the PANalytical X'Pert HighScore Plusprogram using the ICDD pdf-4/minerals database. Only qualitative analysis was carried out.

\subsection{Characterization of Water from Iso Hiislampi Pond}

Water parameter values from Iso Hiislampi pond at four depths were measured on site in June 2010 by handheld YSI Professional Plus Quattro multiparameter water quality meter (Table 2).

Table 2. Water parameter values for Iso Hiislampi pond at four depths.

\begin{tabular}{|c|c|c|c|c|}
\hline \multirow{2}{*}{ Parameter } & \multicolumn{4}{|l|}{ Depth } \\
\hline & $\mathbf{0 ~ m}$ & $8 \mathrm{~m}$ & $13 \mathrm{~m}$ & $13,5 \mathrm{~m}$ \\
\hline $\mathrm{T} /{ }^{\circ} \mathrm{C}$ & 17.6 & 4.1 & 4.1 & 4.1 \\
\hline $\mathrm{O}_{2} \%$ & 94.3 & 8.2 & 4.7 & 2.9 \\
\hline $\mathrm{O}_{2}\left(\mathrm{mg} / \mathrm{dm}^{3}\right)$ & 8.98 & 1.07 & 0.6 & 0.4 \\
\hline Conductivity $(\mu \mathrm{S} / \mathrm{cm})$ & 32.2 & 49.2 & 172.2 & 161.4 \\
\hline $\mathrm{pH}$ & 7.24 & 6.48 & 6.97 & 6.95 \\
\hline Redox (mV) & 160.4 & 34.5 & -57.3 & -67.6 \\
\hline
\end{tabular}

\section{Results and Discussion}

\subsection{Release of Metal Contaminants from the Waste Rock Pile}

Before mining ceased, 7,300 $\mathrm{m}^{3}$ of waste rock was piled alongside the quarries (point 1 in Figure 1) and subsequently covered with clay and till during site remediation in the 1990's. Run-off sediment and water samples were taken from a small stream emanating from the edge of the pile (Figure 1, point 4) in order to study possible release of metals. In addition, soil samples were taken between the waste rock pile and the start of the stream (Figure 1, point 3).

\subsubsection{Metals in Stream Run-off Sediments}

Sediment samples were taken in September 2010 when the ephemeral stream (Figure 1, point 4) was dry over a distance of some $100 \mathrm{~m}$ and in June 2012 when this part of the stream was flowing. From the confluence with the larger water course, the stream continues for $300 \mathrm{~m}$ before draining into Iso Hiislampi pond. The stream may be affected by the waste rock pile along part of its length (between points 3 and 5); therefore, run-off sediment samples from the dry stream bottom were taken along a $100 \mathrm{~m}$ section at $10 \mathrm{~m}$ intervals. Other than $\mathrm{Fe}$ and $\mathrm{Mn}$, metal concentrations along this track do not show any obvious trend; consequently the mean values for the eight samples are given in Table 3 . Concentrations vary over a fairly wide range with the standard deviation being typically $60 \%$ of the means. Arsenic levels are high when compared to average values for Finnish stream sediments [16], by a factor 8 . The reddish-brown colour of the sediment indicates precipitation of iron and it is reasonable to assume that dissolved metals are coprecipitated with iron hydroxides. Iron and manganese concentrations in sediments are clearly higher at the far end of the stream, due to a gradual increase in water $\mathrm{pH}$.

Table 3. Metal concentrations in run-off sediments from a stream draining the waste rock pile into Iso Hiislampi pond at Paukkajanvaara. Reported values are the means of eight samples taken from the seasonally dry upper $100 \mathrm{~m}$ of the stream closest to the waste rock. Mean concentrations in Finnish stream sediments are from [16]. The uncertainty is the standard deviation of mean of eight samples.

\begin{tabular}{lll}
\hline \multirow{2}{*}{ Metal } & Mean concentration $(\mathbf{p p m})$ & Finnish stream sediments \\
\cline { 2 - 3 } & Paukkajanvaara run-off sediments & 4.4 \\
\hline $\mathrm{As}$ & $36 \pm 30$ & 0.2 \\
$\mathrm{Cd}$ & $0.3 \pm 0.2$ & 49 \\
$\mathrm{Co}$ & $42 \pm 26$ & 35 \\
$\mathrm{Cr}$ & $51 \pm 12$ & 45 \\
$\mathrm{Cu}$ & $26 \pm 17$ & 32000 \\
$\mathrm{Fe}$ & 50000 (first 3 samples) 150000 (next 4 samples) & 43 \\
$\mathrm{Mn}$ & 1300 (first 3 samples) 10000 (next 4 samples) & 9.8 \\
$\mathrm{~Pb}$ & $12 \pm 16$ & 56 \\
$\mathrm{Zn}$ & $81 \pm 32$ & \\
\hline
\end{tabular}

\subsubsection{Metals in Stream Water}

Metal concentrations in stream water are not especially elevated compared to average concentrations in average Finnish stream water [16] (Table 4). Values given in Table 4 are the means of nine water samples taken from both the
2010 and 2012 campaigns. Samples were taken upstream of the point at which they might be affected by releases from the mill tailings waste pond, discussed later. They show higher values of $\mathrm{Mn}, \mathrm{Fe}, \mathrm{Ni}, \mathrm{Co}$ and $\mathrm{Zn}$ in samples taken closest to the waste rock pile, probably due to lower $\mathrm{pH}$ values. 
Table 4. Concentrations of metals in five water samples from the stream draining the waste rock pile into Iso Hiislampi pond at Paukkajanvaara (first column). Mean concentrations in Finnish stream waters are from [16]. Reference waters are from a small pond and a stream unaffected by the waste rock pile. Values in the fifth column are mean concentrations of three samples from the distal end of the stream. Values in the sixth column are mean concentrations of five water samples from Iso Hiislampi pond. Uncertainties are standard deviations of means.

\begin{tabular}{llllll}
\hline \multirow{2}{*}{ Metal } & Concentration (ppb) & & & & \\
\cline { 2 - 6 } & $\begin{array}{l}\text { Stream water upstream of } \\
\text { mill tailings }\end{array}$ & Reference waters & $\begin{array}{l}\text { Stream water at mill } \\
\text { tailings site }\end{array}$ & Iso Hiislampi pond & Finnish stream waters \\
\hline $\mathrm{As}$ & $0.7 \pm 0.2$ & $11 / 0.4$ & $2.4 \pm 1.4$ & $0.4 \pm 0.1$ & 0.4 (median) \\
$\mathrm{Cd}$ & $0.03 \pm 0.02$ & $0.3 / 0.1$ & $0.06 \pm 0.04$ & $0.05 \pm 0.03$ & 0.02 (median) \\
$\mathrm{Co}$ & $2.7 \pm 2.9$ & $0.2 / 4.0$ & $7.4 \pm 6.5$ & $0.1 \pm 0.01$ & 0.3 \\
$\mathrm{Cr}$ & $0.7 \pm 0.4$ & $0.6 / 0.6$ & $1.2 \pm 0.4$ & $0.6 \pm 0.3$ & 0.5 (median) \\
$\mathrm{Cu}$ & $1.8 \pm 0.8$ & $1.3 / 1.1$ & $1.1 \pm 0.7$ & $2.3 \pm 0.2$ & 0.4 \\
$\mathrm{Fe}$ & $2000 \pm 1700$ & $680 / 1500$ & $7100 \pm 5000$ & 910 \\
$\mathrm{Mn}$ & $480 \pm 510$ & $72 / 610$ & $1200 \pm 1000$ & $200 \pm 20$ & 1300 \\
$\mathrm{Ni}$ & $6.3 \pm 5.0$ & $3.4 / 4.5$ & $21 \pm 15$ & $21 \pm 8$ & 1.2 \\
$\mathrm{~Pb}$ & $0.2 \pm 0.2$ & $0.06 / 0.01$ & $0.7 \pm 0.7$ & $1.1 \pm 0.1$ & 0.3 \\
$\mathrm{Zn}$ & $4.9 \pm 8.1$ & $7.7 / 8.8$ & $6.4 \pm 5.4$ & 6.02 & 4.6 \\
\hline
\end{tabular}

\subsubsection{Metals in Soil}

In addition to contributions from run-off sediments and stream water, possible release of metals from the waste rock pile was studied by measuring metal concentrations in surface soil samples collected at the edge of the pile, close to the source of the stream (Table 5). The $20 \mathrm{~cm}$ soil cores were divided into three vertical subsamples: $0-3 \mathrm{~cm}$ representing organic topsoil and $3-11 \mathrm{~cm}$ and $11-20 \mathrm{~cm}$ fractions representing the underlying mineral soil. The metals were found at higher abundance in the lower sections but at levels not atypical of Finnish till; indeed, copper and zinc are lower than the mean for Finnish tills [13]. Most elements show no clear trend, though $\mathrm{Cd}, \mathrm{Cu}, \mathrm{Zn}$ and possibly, Co increase with depth.

Table 5. Average concentrations of metals in five soil cores $(0-20 \mathrm{~cm})$ at the edge of the waste rock pile at Paukkajanvaara. The values are mean concentrations of five soil cores. Uncertainties are standard deviations of means.

\begin{tabular}{lllll}
\hline \multirow{2}{*}{ Metal } & Concentration (ppm) & & & \\
\cline { 2 - 5 } & $\mathbf{0 - 3} \mathbf{~ c m}$ organic soil & $\mathbf{3 - 1 1} \mathbf{~ c m}$ mineral soil & $\mathbf{1 1 - 2 0} \mathbf{~ c m}$ mineral soil & Mean concentration in Finnish till [17] \\
\hline $\mathrm{As}$ & $14 \pm 5$ & $5.2 \pm 1.0$ & $6.0 \pm 0.3$ & $3.4 \pm 3.3$ \\
$\mathrm{Cd}$ & $<0.01$ & $0.14 \pm 0.02$ & $0.16 \pm 0.01$ & $0.2 *$ \\
$\mathrm{Co}$ & $9.4 \pm 2.8$ & $10 \pm 2$ & $13 \pm 3$ & $15 \pm 6$ \\
$\mathrm{Cr}$ & $41 \pm 8$ & $54 \pm 16$ & $43 \pm 10$ & $69 \pm 35$ \\
$\mathrm{Cu}$ & $<0.2$ & 1.0 & 1.6 & $24 \pm 14$ \\
$\mathrm{Fe}$ & $16700 \pm 3100$ & $21200 \pm 4300$ & $19700 \pm 3700$ & $33000 \pm 10000$ \\
$\mathrm{Mn}$ & $580 \pm 390$ & $370 \pm 70$ & $550 \pm 50$ & $510 \pm 110$ \\
$\mathrm{~Pb}$ & $5.7 \pm 5.3$ & $22 \pm 13$ & $20 \pm 5$ & 3.2 \\
$\mathrm{Zn}$ & $<0.3$ & 0.4 & 1.5 & $66 \pm 34$ \\
\hline
\end{tabular}

*the value for $\mathrm{Cd}$ is an average value in earth's crust since there is no data for $\mathrm{Cd}$ in [17].

\subsection{Release of Metal Contaminants from the Mill Tailings}

The uranium ore mined at Paukkajanvaara was processed on site, which resulted in the formation of $12000 \mathrm{~m}^{3}$ of mill tailings sludge which was released to a small pond alongside the quarry and processing plant and only some 20 metres from Iso Hiislampi. The pond was completely filled with sludge and later, in the 1990's, was covered with clay and till. In order to study possible release of metals from the mill tailings, samples were collected from the actual waste (point 2, Figure 1), from soil between the waste site and the stream flowing on its eastern side (point 9, Figure 1), from soil between the waste site and Iso Hiislampi pond (point 8, Figure 1), from stream water and from Iso Hiislampi pond water (point 7, Figure 1) and from sediment cores in Iso Hiislampi.

\subsubsection{Metals in Mill Tailings}

Three cores were drilled into the tailings and samples taken at four depths between 2 and 5 metres. Metal concentrations do not vary much with depth except in one core at 4 metres where the values are 2 to 8 -times higher than at other depths and in the remaining cores (Table 6). Compared to average Finnish till concentrations (Table 4), metal concentrations in layers other than the exceptional 4-m layer do not differ significantly. In our previous study [9], it was shown that the $U$ concentration in this layer is very high; on average about 150-times higher than in other layers. It is possible that this material comprises mill tailings displaying varying efficiency in uranium removal. Conversely, the fact that the 4-m layer has a very high concentration of $U$ and low levels of major elements (e.g. Ca, Mn and Fe) suggests that the material may represent uranium concentrate, discarded either accidently or deliberately following the decision to abandon the mine. 
Table 6. Average metal concentrations (ppm) in three mill tailings samples from the former Paukkajanvaara uranium mine. Uncertainties are standard deviations of means.

\begin{tabular}{lllll}
\hline & Average in 2-5 m excluding 4-m layer & 4-m layer & Ratio $\mathbf{4 m} / \mathbf{2 - 5 m}$ & $\begin{array}{l}\text { Ratio of average concentration in 2-5m to } \\
\text { average concentration in Finnish till }\end{array}$ \\
\hline $\mathrm{As}$ & $11 \pm 1$ & 42 & 4.0 & 0.3 \\
$\mathrm{Ca}$ & $3400 \pm 800$ & 9500 & 2.8 & 5 \\
$\mathrm{Cd}$ & L $\mathrm{HD}$ & LOD & & \\
$\mathrm{Co}$ & $14 \pm 9$ & 76 & 5.3 & 1.0 \\
$\mathrm{Cr}$ & $57 \pm 9$ & 140 & 2.5 & 1.2 \\
$\mathrm{Cu}$ & $64 \pm 17$ & 240 & 3.7 & 0.3 \\
$\mathrm{Fe}$ & $19000 \pm 2000$ & 57000 & 3.0 & 1.8 \\
$\mathrm{Mn}$ & $280 \pm 80$ & 2200 & 7.6 & 1.8 \\
$\mathrm{~Pb}$ & $19 \pm 19$ & 350 & 18 & 0.2 \\
$\mathrm{Zn}$ & $51 \pm 14$ & 200 & 4.0 & 1.3 \\
\hline
\end{tabular}

*LOD $=$ below the detection limit

\subsubsection{Metals in Stream Water}

Metal concentrations in the stream water on the eastern side of the mill tailings (Table 3, fifth column) are identical, within the range of uncertainty, with the values observed upstream of the mill tailings (Table 3, second column). Thus, we conclude that the mill tailings do not contribute significant metal contaminant to the stream.

\subsubsection{Metals in Soil Surrounding the Mill Tailings}

Four soil cores were collected between the mill tailings and the stream on its eastern side and six cores between the mill tailings and Iso Hiislampi pond. Cores were collected at about $10 \mathrm{~m}$ intervals. Table 7 presents metal concentrations in three layers from the cores. Few obvious trends in vertical distribution are apparent and the concentrations are similar to those found at the edge of the waste rock pile (Table 4). Metal concentrations are not especially high and it may be concluded that the mill tailings do not leach significant quantities of metals into the surrounding soil. Manganese and zinc reach their highest levels in the organic-rich topsoil. Zinc and copper were not observed in the soils collected between the mill tailings and the pond but between the mill tailings and the stream their concentrations are 40- to 360times higher than in samples close to waste rock pile. These high values, however, represent typical values in Finnish till. The reason for the large variation remains unclear.

Table 7. Concentrations of metals in soil cores $(0-20 \mathrm{~cm})$ at the edge of the mill tailings disposal site at Paukkajanvaara. The depths are approximate. Concentrations are average concentrations in six and four soil cores and the uncertainties are standard deviations of means.

\begin{tabular}{|c|c|c|c|c|c|c|}
\hline \multirow{4}{*}{ Metal } & \multicolumn{6}{|c|}{ Concentration (ppm) } \\
\hline & \multicolumn{3}{|c|}{$\begin{array}{l}\text { Soil between the mill tailings site and the stream (mean of four soil } \\
\text { cores) }\end{array}$} & \multicolumn{3}{|c|}{ Soil between the mill tailings and the pond (mean of six soil cores) } \\
\hline & \multicolumn{3}{|c|}{ Depth } & \multicolumn{3}{|l|}{ Depth } \\
\hline & $0-2 \mathrm{~cm}$ & $2-10 \mathrm{~cm}$ & $10-21 \mathrm{~cm}$ & $0-3 \mathrm{~cm}$ & $3-10 \mathrm{~cm}$ & $10-18 \mathrm{~cm}$ \\
\hline As & $9.4 \pm 1.9$ & $10 \pm 1$ & $11 \pm 1$ & $5.1 \pm 2.7$ & $3.8 \pm 0.6$ & $4.1 \pm 0.6$ \\
\hline $\mathrm{Cd}$ & n.d. & n.d. & n.d. & n.d. & n.d. & n.d \\
\hline Co & $12 \pm 7$ & $9.1 \pm 1.4$ & $10 \pm 1$ & $9.1 \pm 3.2$ & $8.8 \pm 1.4$ & $9.5 \pm 1.4$ \\
\hline $\mathrm{Cu}$ & $32 \pm 9$ & $46 \pm 15$ & $66 \pm 11$ & n.d. & n.d. & n.d. \\
\hline $\mathrm{Fe}$ & $20000 \pm 3300$ & $22000 \pm 2400$ & $17000 \pm 3300$ & $16000 \pm 2500$ & $18000 \pm 2700$ & $19000 \pm 2100$ \\
\hline $\mathrm{Mn}$ & $1000 \pm 1200$ & $230 \pm 20$ & $250 \pm 70$ & $420 \pm 180$ & $300 \pm 40$ & $330 \pm 100$ \\
\hline $\mathrm{Pb}$ & $14 \pm 2$ & $17 \pm 6$ & $10 \pm 1$ & $7.2 \pm 3.7$ & $12 \pm 6$ & $13 \pm 7$ \\
\hline $\mathrm{Zn}$ & $110 \pm 50$ & $57 \pm 17$ & $53 \pm 7$ & n.d. & n.d. & n.d \\
\hline
\end{tabular}

\subsection{Metals in Iso Hiislampi Pond}

\subsubsection{Metals in Pond Water}

Metal concentrations in water from Iso Hiislampi pond were similar or lower than in the stream (Table 4, sixth column).

\subsubsection{Metals in Lake Sediment}

Three sediment cores were collected from the bottom of Iso Hiislampi, approximately in the centre of the pond at a water depth of 14-15 m. Two of the three cores were analysed by X-ray diffraction (XRD) in order to identify the main minerals present. The uppermost layers $(0-5 \mathrm{~cm})$ are amorphous and dark brown in colour owing to the abundance of organic matter. Typically, bottom sediments in this type of ponds have sediments originating from humic substances released from the surrounding soils and marshlands. Between about 6 and $9 \mathrm{~cm}$ there was dense grey sludge below which the sediment again became dark brown. The layer at 5-6 cm mainly contains quartz whereas the deeper layers comprise a mixture of quartz, mica (mostly muscovite) and kaolinite. No dating of the sediments was carried out but data from 12 cores taken from 6 similar lakes within $200 \mathrm{~km}$ of Paukkajanvaara show annual sedimentation of organic matter on the order $0.12 \pm 0.0 .4 \mathrm{~mm}$ [18]. Assuming that this applies to Iso Hiislampi, sedimentation of the uppermost $6 \mathrm{~cm}$ of the cores occurred during the 50 years between the mine closing and the current sampling campaign. The grey material 
observed between 6 and $9 \mathrm{~cm}$ probably consists of releases from the mill tailings pond with the material below that dating from the pre-mining period.

Figure 2 presents the mean metal concentrations in the cores. There is a peak value for most metals at $6-8 \mathrm{~cm}$ which we assume to originate from mill tailings released during mining. Further, while it is evident that the concentrations of metals increased after the mine closed it is notable that this increase has continued, at least in the case of $\mathrm{Fe}, \mathrm{Co}, \mathrm{Cu}, \mathrm{Cd}$,

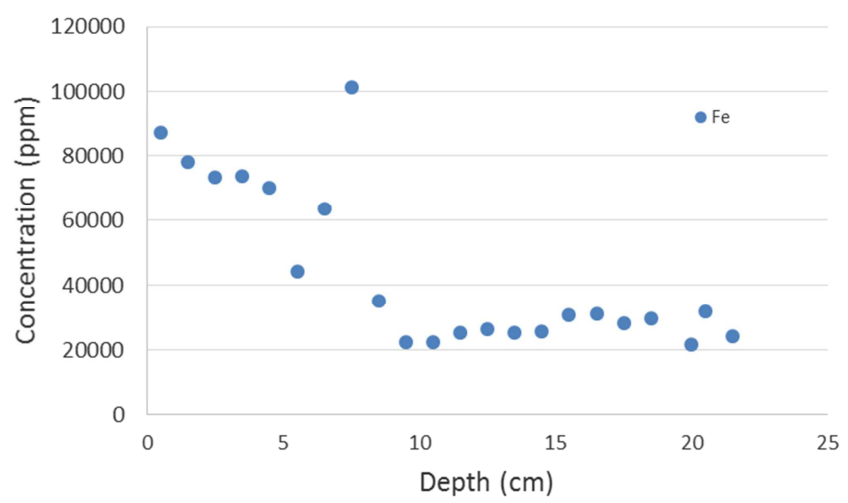

and As, even after remediation of the area some 20 years before our sampling campaign (upper $2-3 \mathrm{~cm}$ ). Comparison of the average concentrations of metals in the cores with those of a similar lake, Lentiira (Aittoselkä) in Kuhmo, about 160 $\mathrm{km}$ north of Paukkajanvaara, shows that concentrations of $\mathrm{Cu}$, As and $\mathrm{Pb}$ are higher at Paukkajanvaara, by a factor of 4 to 9, while concentrations of $\mathrm{Mn}, \mathrm{Fe}, \mathrm{Cd}$ and $\mathrm{Zn}$ are similar in both lakes [18]. No data for $\mathrm{Cr}$ and $\mathrm{Co}$ for Lentiira are available.
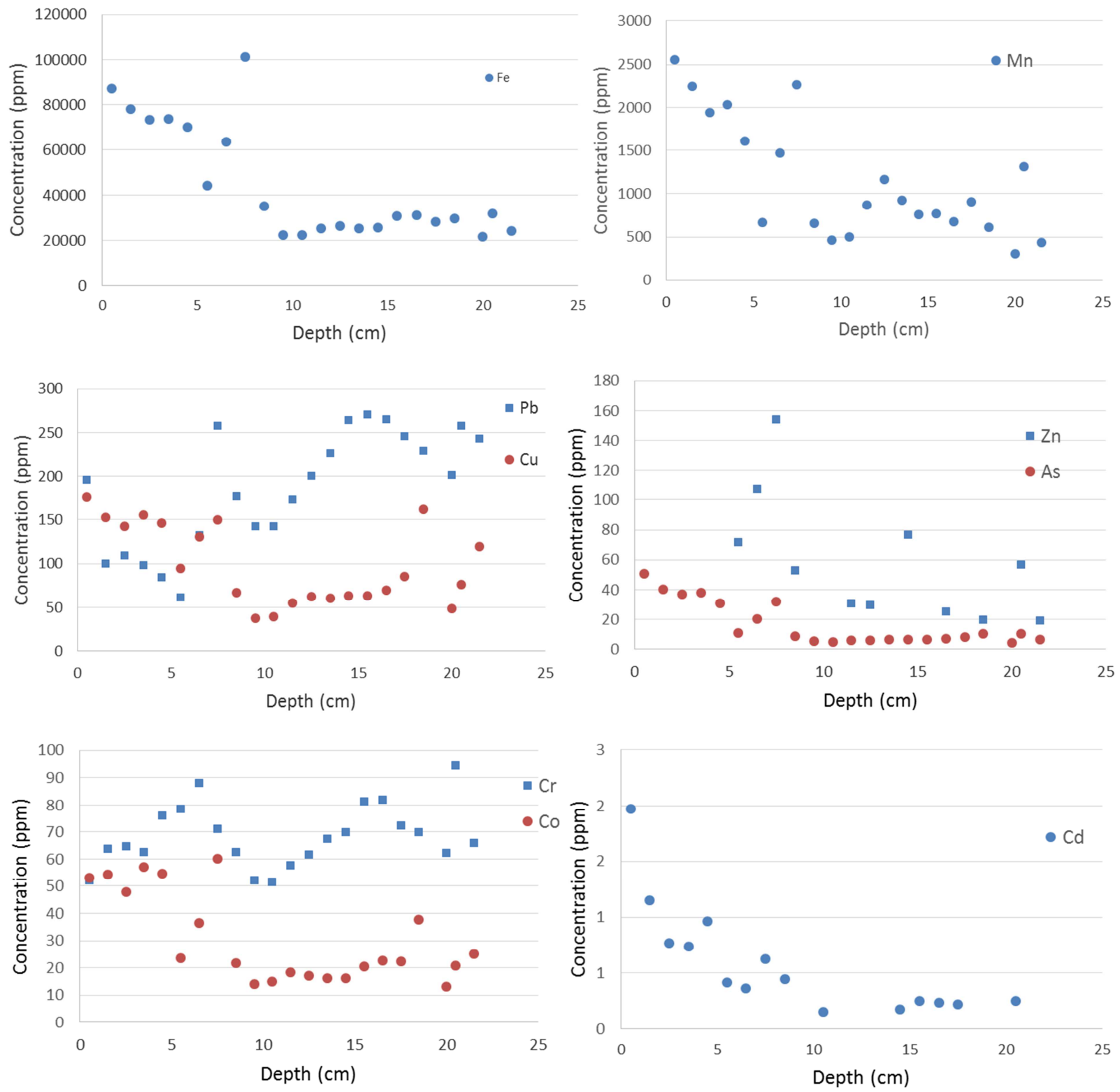

Figure 2. Metal concentrations in the Iso Hiislampi lake sediments at the former Paukkajanvaara uranium mine site. The values are means of metal concentrations in the three. The standard deviation of the three concentration values varied on average by $34 \%$, being highest for Cd at $95 \%$ and lowest for $\mathrm{Fe}$ and $\mathrm{Co}$ at $13 \%$.

\section{Conclusions}

This study focused on possible leaching of metals from waste rock and mill tailings from a former pilot-scale test uranium mine at Paukkajanvaara in Eastern Finland into surrounding water systems. Water, soil, lake and stream sediments, as well as mill tailings samples were collected and their base and potentially harmful metal concentrations were determined. In general the metal concentrations were at typical environmental levels in Finland and the metal concentrations determined in water, soil and sediment samples show that waste rock and processed waste at the 
former Paukkajanvaara uranium mine in Eastern Finland do not leach substantial potentially harmful metals into surrounding water systems. The increasing trend of metal concentrations in pond sediments, however, shows that some leaching is taking place. In conclusion, we may state that the site is not a big if any threat to the environment and humans.

\section{Acknowledgements}

This study was made possible by a research grant from the Academy of Finland. Thanks are extended to Dr. Caroline Kirk for her comments and involvement in mineral characterization.

\section{References}

[1] Masindi, V. and Muedi, K. L. 2018. Environmental Contamination by Heavy Metals, IntechOpen, DOI: 10.5772/intechopen.76082.

[2] Li, Z., Ma, Z, Janvan, van der Kuijp, T. J., Yuan, Z., and Huang, L. 2014, A review of soil heavy metal pollution from mines in China; Pollution and health risk assessment, Science of the Total Environment 468-469; 843-853.

[3] Abraham, J., Dowling, K. and Florentine, S. 2018. Assessment of potentially toxic metal contamination in the soils of a legacy mine site in Central Victoria, Australia, Chemosphere 192; 122-132.

[4] Ebenebe, P. C., Shale, K., Sedibe, M., Tiklili, P. and Achilonu, M. C. 2017. South African mine effluents; Heavy metal pollution and impact on the ecosystem, International Journal of Chemical Sciences 15 (4); 1-12.

[5] Mustonen R., Ikäheimonen T. K., Salonen L. and Sillanpää T. 1989. Uraanin louhinnan ja rikastuksen radiologiset ympäristövaikutukset Enon Paukkajanvaarassa. Finnish Centre for Radiation and Nuclear Safety, Report STUK-BVALO 61.

[6] Colpaert A. 2006. The forgotten uranium mine of Paukkajanvaara, North Karelia, Finland. Nordia Geographical Publications 35; 31-38.

[7] Räisänen K. 1961. Atomienergia Oy; $n$ toimesta suoritetut uraanimalmien louhinta ja rikastuskokeilut vv. 1958-1961. Vuoriteollisuus - Bergshanteringen 2; 34-43.

[8] Sillanpää T., Ikäheimonen T., Salonen L., Taipale T. and
Mustonen R. 1989. Paukkajanvaaran vanhan uraanikaivos- ja rikastamoalueen ja sen ympäristön radioaktiivisuustutkimukset. Report STUK-B-VALO 56, Finnish Centre for Radiation and Nuclear Safety.

[9] Tuovinen H., Pohjolainen E, Vesterbacka D., Kaksonen K., Virkanen J., Solatie D., Lehto J. and Reid D 2016. Release of radionuclides from waste rock and tailings at a former pilot uranium mine in eastern Finland. Boreal Environment Research 21; 471-480.

[10] Dreesen, D. R., Williams, J. M., Marple, M. L., Gladney, E. S. and Perrin, D. R. 1982. Mobility and bioavailability of uranium mill tailings contaminants, Environmental Science and Technology 16; 702-709.

[11] Landa, E. 1999. Geochemical and biogeochemical controls on element mobility in and around uranium mill tailings. In; Filipek, L., Plumlee, G. (Eds.) Environmental Geochemistry of Mineral Deposits, Part B. Case studies and Research Topics, Reviews in Economic Geology, Vol. 6B, Littleton, Society of Economic Geologists, 527-538.

[12] Lottermoser, B. 2007. Mine wastes. Characterization, Treatment, Environmental Impacts. Second Edition. Springer, Berlin. 304.

[13] Piirainen, T. 1968. Die Petrologie und die Uranlagerstätten de Koli-Kaltimogebiets im finnischen Nordkarelien. Bulletin of Geological Society of Finland. N; o 237, 99p.

[14] Makkonen H. T., Mikkonen J. A., Ruotanen K. E., Tanskanen P. A.. Uusikartano A. J., Vuollo J. I. 1988. Paukkajanvaaran uraanimineralisaatiot. Pohjois-Karjalan malmiprojekti. Raportti 17. Oulu, Oulun yliopisto.

[15] Tuovinen H., Vesterbacka D., Pohjolainen E., Read D., Solatie D. and Lehto, J. 2015 A Comparison of analytical methods for determining uranium and thorium in ores and mill tailings, Journal of Geochemical Exploration 148; 74-180.

[16] Lahermo P., Väänänen P., Tarvainen T. and Salminen R. 1996. The Geochemical Atlas of Finland, Part 3; Environmental Geochemistry-stream waters and sediments. Geological Survey of Finland.

[17] Koljonen T. (ed.) 1992. The Geochemical Atlas of Finland, Part 2; Till. Geological Survey of Finland.

[18] Lehto J., Lusa M., Virkanen J., Paatero J., Várkonyi G., Heikkilä R., Kashevarov B. and. Ieshko E. 2010. Metal distribution in lakes surrounding the Kostomuksha iron mine and ore dressing mill in Northwestern Russia, Air, Soil and Water Research 3; 67-77. 